\author{
Nama : Rezki Amalia Fathurrahman \\ Jurusan : Ekonomi Islam C \\ Nim : 90100118108
}

\title{
Hubungan Kapitalisme dan Produksi
}

Di dunia jumlah kekayaan diseluruh dunia adalah 359 orang terkaya didunia yang setara dengan jumlah kekayaan 2,9 Miliar orang-orang termiskin didunia. Yang dimana terdapat 5 Miliar penduduk di bumi yang terdapat orang kaya hanya 359 orang jika di rata-ratakan kekayaan mereka sama dengan jumlah kekayaan separuh dari jumlah penduduk di bumi. Misalkan jika 3 orang kaya di dunia bila digabungkan dengan sama dengan GDP 48 negara miskin. Maka dari itu untuk mengatasi permasalahan penduduk di dunia seperti ketersediaan kebutuhan makanan, air, pendidikan dan kesehatan serta mengatasi kelaparan, kekurangan gizi dan wabah penyakit, maka dibutuhkan adalah $4 \%$ dari akumlasi kekayaan dari 255 orang terkaya di dunia. Agar bisa memenuhi kebutuhan seperti kesehatan dan makanan maka biaya yang diperlukan sebesar \$13 Miliar yang jika dihitung setara dengan pengeluaran pembelian parfum di Eropa.

Fakta di atas bisa disimpulkan bahwa terjadinya kesenjangan apa itu dari pendapatan atau kekurangan kebutuhan pokok. Dan juga terjadi kontradiksi yang terjadi di masyarakat karena di tengah kesejahteraan dan kekayaan ternyata kemiskinan masih terjadi sehingga terjadi reproduksi kemiskinan dan kesengsaraan yang terus menerus terjadi. Dalam 300 tahun terahkir ini kontadiksi masih terus berlanjut karena pada saat terjadi pembangunan selalu bersamaan dengan jumlah kemiskinan. Maksudnya adanya pembangunan selalu sejalan dengan ketertinggalan. Agar tidak tertinggal maka di perlukan adanya jalan untuk menuju kesuksesan.

Menapaki tangga kesuksesan ini diperlukan adanya kerja keras dan berusaha untuk mendapatkan posisi lebih baik. Inilah yang disebut dengan aturan pokok yang mengatur kehidupan sosial saat ini. Akan tetapi aturan tersebut tidak 
semua orang bisa menapakinya karena masyarakat bukan penjumlahan atau gabungan dari bagian atau indvidu, maksudnya setiap individu akan menjalani nasib sendiri apakah menjadi sukses atau hidup di satu tempat tidak melakukan perubahan.

Kehidupan masyarakat yang alami saat ini yang disebut dengan kapitalisme. Yang dimana kapitalisme adalah suatu sistem ekonomi sosial yang bercirikan kepada profit motive atau keuntungan yang dikontrol oleh sarana produksi, distribusi dan petukaran dan kepemilikan pribadi. Jadi sistem sosial ekonomi saat ini lebih cenderung kepada profit motive yang lebih mendominasi pada prinsip keuntungan dan private property atau kepemilikan pribadi yang saling berhubungan.

Selanjutanya akan menjelaskan bagaimana profit motive dan private proverty bisa berhubungan dalam sarana produksi. Dalam hubungan ini ada yang di namakan dengan the money circuit of capital yang memiliki rumus $\mathrm{M}$ adalah uang dan $\mathrm{C}$ adalah nilai komoditas yang dimana jika modal digunakan untk membeli komoditas lalu komoditas itu di jual kembali akan menghasil keuntungan yang dimana digunakan untuk menambah modal. Rumus yang di jelas tadi adalah.

\section{M-C-M'}

Rumus tadi akan mengalami siklus yang dimulai uang digunakan untuk jadikan komoditas dan komoditas ini dijadikan uang untuk dijual kembali sehingga terjadi siklus yang dinamakan the money circuit of capital . rumus digunakan untuk siklus ini adalah $\mathrm{M}^{\prime}=\mathrm{M}+\Delta \mathrm{M}$, dimana $\Delta \mathrm{M}$ sama dengan keuntungan yang didapat. Siklus tadi tidak berhenti sampai disitu saja, kapitalis setelah mendapatkan M' ini ia mencari keuntungan dengan membeli komoditas C' untuk mendapatkan keuntungan lagi dari M' dan begitu seterusnya. Sehingga terjadi akumulasi tak terhingga jika menggunakan $\mathrm{M}$ dan $\mathrm{C}$ tadi.

Selanjutnya bagaimana money circuit of capital ini bisa berhubungan antara profit dan produksi agar meningkat. Karena agar profit dan produksi berhubungan 
maka diperlukan dua hal penting. Pertama, sarana produksi, distribusi dan pertuksran harus berkonsentrasi pada satu tangan maksudnya harus ada tenaga kerja. Kedua, pasar tenaga kerja, adalah sebuah pasar dimana orang-orang ingin bekerja untuk mendapatkan upah. Jika tidak ada dua hal ini maka tidak ada profit motive untuk menghasilkan keuntungan. Adapun rumus ini akan menjadi

\section{M-C akan menghasilkan LP dan MP akan menghasilkan......P...... C'- M'}

C dibagi menjadi dua bagian ada LP adalah labour power dan MP adalah means of production. labour power adalah seseorang yang memiliki kapasitas kerja untuk dijual oleh pekerja kepada si kapitalis sedangkan means of production adalah segala instrumen yang digunakan oleh labour power ketika bekerja untuk menghasilkan produk baru. Jadi proses produksi ini disimbolkan dengan .......... untuk mendapatkan penggunaan energi hidup dalam proses produksi maksud disini tenaga kerja baru atau sarana produksi baru. Sehingga menghasilkan C' adalah komoditi baru dengan nilai baru yang nantinya akan dijual menghasilkan $\Delta \mathrm{M}$ atau M'. jadi inti dari money circuit of capital adalah tenaga kerja yang bisa disimpulkan dengan akumulasi tanpa batas dan kerja tanpa batas. Motto hidup bagi kapitalis adalah motif mencari keuntungan tanpa batas. 